\title{
Aquele Evento, Esta Memória: notas sobre a Antropologia das Diásporas Africanas no Novo Mundo ${ }^{1}$
}

\author{
David Scott \\ Tradução: Rogério Brittes W. Pires \\ Universidade Federal de Minas Gerais, Belo Horizonte, Brasil \\ E-mail:rogeriobwp@gmail.com \\ Tradução: Julia Sauma \\ PNPD-CAPES/USP, São Paulo, Brasil \\ E-mail:juliasauma@gmail.com
}




\section{Resumo}

Neste artigo de 1991, David Scott analisa importantes marcos da antropologia estadunidense acerca dos povos de ascendência africana no Novo Mundo: o trabalho de Melville Herskovits, nos anos 1920 a 1940, e o de Richard Price, nos anos 1970 e 1980 - dando ênfase às pesquisas de ambos entre os Saamaka do Suriname, que figuram como "uma espécie de metonímia antropológica" nas discussões sobre a diáspora africana nas Américas. Scott buscará compreender como a "ciência da cultura" fundada por Boas construiu "o Negro do Novo Mundo" como objeto teórico e passou a fornecer o vocabulário autorizado capaz de identificá-lo e de representá-lo. $\mathrm{O}$ autor tece críticas ao modo como tal antropologia constrói uma narrativa de continuidades entre memórias precisas no presente e os tropos "África" e "escravidão" em passados autênticos e verificáveis, para depois propor aquelas que considera serem as tarefas teóricas adequadas para o complexo campo discursivo da "tradição".

Palavras-chave: Negro do Novo Mundo. Antropologia Cultural. África; Escravidão. Saamaka.

\section{Abstract}

David Scott's 1991 article examines important landmarks of the North American anthropology of peoples of African descent in the New World: the works of Melville Herskovits in the 1920s, '30s and '40s and of Richard Price in the 1970s and '80s, focusing on the researches both conducted among the Saamaka of Suriname, depicted as "a sort of anthropological metonym" in the debates about the African diaspora in the Americas. Scott traces how the "science of culture" established by Boas constructed "the New World Negro" as a distinctive theoretical object and became the discipline authorized to provide the vocabulary employed to identify and represent it. The author criticizes the anthropological construction of a narrative of continuities between accurate memories in the present and the tropes "Africa" and "slavery" in authentic, verifiable pasts, and proposes a set of theoretical questions he considers more pertinent about the complex discursive field of "tradition".

Keywords: New World Negro. Cultural Anthropology. Africa. Slavery. Saamaka. 
Era o lado Atlântico da ilha, um mar saqueador, arregalado, cor de pedra, profundo e cheio de correntes perigosas, revestido de camadas após camadas de barreiras de corais, com um som como um lamento incessante, das vozes unidas de todos os afogados - todos aqueles, diz-se nove milhões ou mais, que morreram em seu exílio forçado, em sua diáspora, afundando entre este ponto e a terra-mãe à leste, fora do alcance dos olhos. Aquele mar estava de luto por eles. Ofendido, ultrajado, desgostoso, arremessava-se contra cada coral e depois contra os seixos da praia, lançando escuma em um babujar raivoso que o vento levava como fumaça sobre a terra. Grandes rochas que há séculos rugiram desde Westminster permaneciam espalhadas pela ressaca, esculpidas pelo vento e pela água em formas fantásticas, como se fossem lápides enaltecendo os milhares que se afogaram.

(Paule Marshall, The Chosen Place, the Timeless People. O Local Escolhido, as Pessoas sem Tempo).

\section{Entre o Velho e o Novo Mundo, o Passado e o Presente ${ }^{2}$}

Tessa passagem inesquecível, Paule Marshall evoca a relação entre o 1 passado e o presente da diáspora africana, entre o trauma histórico de um evento inaugural e a nossa memória coletiva do mesmo. Neste ensaio, vou tratar de certa maneira de ler tal relação, maneira essa que, ao meu ver, tem sido elemento central na identidade da antropologia dos povos de ascendência africana no Novo Mundo; e que, acredito também, estaria equivocada.

Essa antropologia - desde seu advento formal no trabalho de Melville J. Herskovits no final da década de 1920 até sua elaboração atual na obra de afro-americanistas e afro-caribeanistas contemporâneos como Sidney Mintz e Richard Price - girou, de modo bastante profundo, em torno de uma narrativa de "continuidades". Continuidades entre o 
Velho e o Novo Mundo, o passado e o presente. As razões para o privilégio e para a persistência de tal narrativa no arquivo dessa antropologia não são difíceis de encontrar. Afinal, sabe-se que a presença africana no Novo Mundo começou com uma abrupta e irreversível ruptura nos porões dos navios negreiros que cruzavam a "passagem do meio" e, em circunstâncias históricas de desorganização e reorganização social sem precedentes, nas plantations escravistas coloniais. Previsivelmente, a antropologia manifesta profunda inclinação humanista por uma história sobre continuidades e assume a zelosa tarefa de demonstrar, nessas sociedades, a integridade e a plenitude do velho no novo, e do passado no presente. Tampouco é surpreendente que, no urdir dessa narrativa de continuidades, a "África" e a "escravidão" aparecem para formar seus pontos de referência gerativos e constitutivos.

Obviamente, essa história de continuidades não está confinada aos parâmetros disciplinares da antropologia. É uma história que de varias formas estruturou nossa própria "comunidade imaginada", nossas próprias narrativas de identidade e tradição. Por esse motivo, seria possível (para não dizer pertinente) falar aqui sobre ao menos dois registros historicamente interconectados, porém distintos e analiticamente separáveis. O primeiro é, estritamente falando, antropológico, pois relacionado à construção disciplinar de um objeto teórico singular, a saber, "o Negro do Novo Mundo"3 (para usar seu nome inaugural) e ao aparato conceitual empregado para identificá-lo e representá-lo. Poderíamos dizer que o outro seria extra-antropológico, transdisciplinar, por vezes positivamente antidisciplinar, e relacionado a variados discursos político-culturais de identidade e de tradição produzidos por povos de ascendência africana no Novo Mundo no decurso de nossas próprias práticas e lutas ${ }^{4}$.

Esses registros culturais produtores de conhecimento certamente não são idênticos, mas o notável é que, mesmo no discurso não antropológico, a antropologia, tomada como a (autodenominada) "ciência da cultura", é amiúde vista como crucial para fornecer o vocabulário autorizado em cujos termos as reivindicações de diferença são estabelecidas. A antropologia - e, por razões históricas bem definidas, a antropologia cultural americana mais especificamente - é frequentemente tomada como fornecedora daquilo que podemos 
chamar de discurso fundacional das políticas culturais de identidade entre povos de ascendência africana no Novo Mundo 5 . Esse certamente é o caso desde, pelo menos, o famoso discurso de patrono dado por Franz Boas na Atlanta University em 1906, sob convite de W. E. B. Du Bois ${ }^{6}$. E tornou-se o caso de forma mais clara e decisiva, duas décadas depois, com o trabalho seminal de Herskovits.

Quero examinar aqui o lado especificamente disciplinar desta preocupação com a continuidade. Entendo que, ao deixar de lado os textos ditos "nativos" meu exercício pode ser apenas parcial. Eu aceito isso. Mas se a antropologia, em suas capacidades como ciência da cultura, foi capaz de reivindicar para si - ou tem reivindicado - o papel de autoridade superior ou mais fundamental na questão da diferença cultural, então há um trabalho inicial ou uma interrogação disciplinar interna a ser levada a cabo, uma contabilidade crítica prévia acerca do tipo de objeto teórico que essa antropologia estabelece e faz circular, em seus textos autorizados, sobre as práticas culturais de povos de ascendência africana no Novo Mundo ${ }^{7}$.

Em primeiro lugar, delinearei a tese defendida por uma contribuição recente a essa antropologia, First-Time: The Historical Vision of an AfroAmerican People (Primeiros Tempos: A Visão Histórica de um Povo Afro-Americano), de Richard Price (1983a). Ao fazê-lo, não apenas enfatizarei algumas das premissas conceituais do argumento de Price acerca de um passado no qual a escravidão gera o referente mais importante, como também examinarei os pressupostos ideológicos do problema especificamente antropológico estabelecido por meio de tal argumento. Isso me levará a um exame acerca da relação dessa tese com a problemática inaugural do "Negro do Novo Mundo", formulada por Herskovits, em cuja obra é a África, e não a escravidão, que gera o referente mais importante. Buscarei argumentar que, na economia narrativa ou discursiva dessa problemática antropológica, escravidão e "África" funcionam como termos praticamente intercambiáveis ou, de outra forma, que a escravidão na obra de Price trata de realizar a mesma tarefa retórico-conceitual que a África realiza na obra de Herskovits. Ambos giram em torno da tentativa característica de localizar as "culturas" dos ex-africanos/ex-escravos em relação ao 
que podemos chamar de um passado autêntico, isto é, um passado antropologicamente identificável, etnologicamente recuperável e textualmente re-apresentável ${ }^{8}$. Particularmente revelador é o fato de que tanto Price quanto Herskovits buscam ilustrar seus argumentos sobre os passados e culturas de povos de ascendência africana no Novo Mundo com base no estudo de um mesmo povo, os saamaka ${ }^{9}$ do Suriname ${ }^{10}$.

Minhas divergências serão evidentes, mas minha razão principal ao adotar tal estratégia não seria criticar Price ou Herskovits. Mais importante, meu objetivo tampouco seria renunciar ao tropo das continuidades como tal, ou a qualquer uma (ou ambas) dessas figuras tão produtivas - a África e a escravidão - por meio das quais essa descrição de continuidade foi teoricamente construída. Como já sugeri, no trabalho dos afro-americanistas e afro-caribeanistas, o discurso proeminente de continuidade é, em parte, a medida do caráter benevolentemente afirmativo da antropologia dos povos de ascendência africana no Novo Mundo; a marca singular, pode-se dizer, de seu intenso humanismo. Minha intenção é, antes, indicar aqueles que me parecem ser os limites desta concepção em sua forma atualmente construída no discurso autorizado da antropologia; sugerir que examinar a formação conceitual de objetos como "o Negro do Novo Mundo" pode ser importante na avaliação de estratégias teóricas; e esboçar os contornos de uma espécie de estratégia alternativa que retém uma preocupação com continuidades de maneira teoricamente mais fecunda para a investigação histórica e antropológica, ou ao menos para a investigação crítico-cultural.

\section{Primeiros Tempos ${ }^{11}$}

"No tempo houve um dia que apagou os últimos olhos que viram Cristo" (Borges, 1984). É usando essa arrebatadora e evocativa citação de Jorge Luís Borges como epígrafe que Richard Price, possivelmente o principal antropólogo dos saamaka da floresta tropical surinamesa, abre sua aclamada etnografia First-Time: the Historical Vision of an Afro-American People. Trata-se, sem dúvida, de uma etnografia da maior importância que, de fato, foi mais de uma vez citada como 
exemplo do que há de melhor em experimentação na escrita etnográfica contemporânea $^{12}$. É possível que seja mesmo. Nesta obra inovadora Price envolve-nos a um nível admirável nas condições de negociação de seu trabalho de campo e em alguns de seus dilemas éticos e epistemológicos. Seja como for, não é como texto etnográfico exemplar que contemplo esta obra aqui; tratarei das estratégias textuais que esse texto utiliza apenas na medida em que sustentam seu argumento substantivo. Do meu ponto de vista, o livro de Price é importante precisamente porque sua estratégia textual oferece uma abordagem inovadora para um problema antropológico particular, cuja aparente natureza realmente me interessa.

A epígrafe escolhida por Price é a primeira e mais importante pista para a estrutura geral do seu compromisso: a questão da existência de uma consciência coletiva viva do passado na diáspora africana. Assim, nas evocativas linhas iniciais de seu trabalho, ele escreve:

Num bosque sagrado ao lado da aldeia de Dangogo, à sombra das árvores equatoriais, ergue-se um desgastado altar para as pessoas dos velhos tempos (awonenge), os ancestrais que ouviram "as armas da guerra". Quando há uma crise coletiva na região - se as chuvas recusarem-se a vir na hora certa ou se uma epidemia tomar conta do rio - é a este altar que os saamaka recorrem. Enquanto as libações de garapa umedecem a terra sob as bandeiras recémerguidas, as pessoas dos velhos tempos são invocadas uma a uma - seus nomes falados (ou tocados no tambor apinti), seus feitos recontados, suas peculiaridades relembradas, e os toques/danças/canções que um dia amaram são executados para dá-los deleite especial. (Price, 1983a, p. 5)

Os saamaka, um povo do Novo Mundo, cuja população hoje chega a aproximadamente $20 \mathrm{mil}^{13}$, são descendentes de africanos vendidos como escravos na Guiana Holandesa (atual Suriname) no final do século XVII e início do XVIII. Entretanto, esses ancestrais, ou as "pessoas dos velhos tempos", escaparam para as florestas do interior e ali estabeleceram comunidades "maroons" 14 fortemente independentes do sistema colonial escravista da costa (Price, 1976; 1983b). Juntamente com as comunidades maroons vizinhas ndyuka, aluku e kwinti, os saamaka permaneceram como povos distintos e 
mais ou menos precariamente autônomos até os dias de hoje. ${ }^{15}$ Se a história da vinda de africanos para o Novo Mundo - sua captura, seu desenraizamento, sua escravização - é contada como tragédia (como o é por historiadores modernos, na maioria das vezes), então seus mais cativantes heróis são os maroons; ${ }^{16} \mathrm{o}$ mais extraordinário exemplo de resistência coletiva continuada na história da escravidão colonial do Novo Mundo. Escravos africanos que escaparam das garras da plantation colonial cedo o suficiente para evitar influência cultural europeia, e em números grandes o suficiente para estabelecer comunidades independentes em solo americano. Nenhum outro povo do Novo Mundo parece melhor exemplificar o momento de trânsito entre o velho e o novo, entre o passado e o presente.

Price abre seu argumento em First-Time com o que lhe parece ser o seu paradoxo conceitual essencial: ao passo que milhares de indivíduos saamaka, ele diz, devem ter de fato "escutado as armas da guerra", isto é, devem ter de fato vivido o tempo das guerras coloniais (entre a década de 1680 e o tratado de paz de 1762), os nomes de apenas uma pequena fração desses ancestrais são hoje invocados no altar para as pessoas dos velhos tempos. Logo, Price sustenta, a história (pela qual ele entende a "consciência" de um passado identificável) é claramente "seletiva". E a singularidade de First-Time, sugere ele,

[...] reside em levar a sério a seleção feita pelas pessoas que se reúnem nesse altar. O livro é sobre aquelas pessoas e aqueles eventos longínquos sobre os quais os saamaka hoje escolhem pensar, falar, e agir; mas é também sobre como os saamaka transformam o passado geral (tudo aquilo que aconteceu) no passado significante, sua historia. Este livro é uma tentativa de comunicar algo da visão particular que os saamaka têm sobre seus anos formativos. (Price, 1983a, p. 5)

E Price efetivamente comunica algo desta visão particular dos saamaka, com cuidado rigoroso e generosidade etnográfica evidente. Ao lermos sobre a lendária Fankia que "ouviu as armas da guerra" e comunicou ao seu povo como deveriam falar com pessoas dos velhos tempos dali em diante, sentimos a força de um passado profundo 
e exigente e vemos como, para os saamaka, Fankia instancia um local inaugural de autoridade histórica. Porém, como veremos, o livro de Price é mais que uma tentativa de transmitir o sabor da visão histórica saamaka. Na verdade, ele busca corroborar tal visão, colocando diante de nós provas advindas de fontes coloniais que supostamente confirmam os eventos sobre os quais seus informantes saamaka falam como verdades históricas que realmente aconteceram. Entre o desejo de compartilhar conosco a "visão singular" dos saamaka, por um lado, e, por outro, a vontade de confirmar a verdade histórica de suas afirmações certamente há um deslizamento, e este forma a tensão central de First-Time, fazendo do livro uma instância exemplar do tipo de problemática antropológica (para mim pouco satisfatória) que vê como sua tarefa representar passados autênticos.

O conhecimento dos primeiros tempos, isto é, o conhecimento daquela era inaugural de embate contra o exército colonial neerlandês, é crucial para a cultura e identidade coletiva saamaka. Tal conhecimento marca para eles uma quebra temporal e mesmo espacial, um limite para o exílio e a escravidão que atravessaram com sacrifício contínuo, e que agora deve ser preservado para as gerações vindouras como uma ameaça constante de um possível retorno que deve ser prevenido, a todos os custos ${ }^{17}$. Como resultado, o conhecimento dos primeiros tempos é distinguido, por exemplo, do conhecimento de um passado mais recente, por aquilo que Price chama de "seu sobrepujante poder inerente" (Price, 1983a, p. 6). Trata-se de uma área do saber local que é "singularmente circunscrita, restrita e guardada" (Price, 1983a, p. 6). Conhecimento que, como Price nos informa, requer cuidados especiais (pois tal conhecimento, dizem os saamaka, pode "matar"); requer ocasiões especiais de elocução (por exemplo, "ao cantar do galo", nas horas que antecedem o alvorecer); e depositários especiais (indivíduos saamaka que, por uma razão ou outra, tornaram-se repositórios do saber histórico saamaka).

Além disso, o conhecimento dos primeiros tempos requer formas discursivas de elocução especiais. É interessante que os saamaka não possuam nenhuma Grande Narrativa de suas origens, nenhuma espécie de história única e interconectada que passe por fases discerníveis e 
sucessivas de começo, meio e fim, trazendo-nos daquele dia a este. Ao invés disso, o conhecimento dos primeiros tempos é integrado em uma variedade de formas discursivas ou retóricas: Price as descreve, incluindo "fragmentos genealógicos", epítetos pessoais, toponímias comemorativas, provérbios, canções, etc. Esse conhecimento é sobretudo o conhecimento de "eventos". Para os saamaka, sustenta Price, é o "evento" que constitui a "substância/matéria da história":

No presente livro, minha unidade de análise é o evento. Tomando fragmentos (frequentemente uma mera frase) de vários homens diferentes, comparando-os, discutindoos com outros, colocando-os em disputa com relatos concorrentes, e eventualmente cotejando-os com dados escritos contemporâneos aos eventos, tento revelar uma imagem do que os mais sábios saamaka sabem, e do porquê sabê-lo e preservá-lo. (Price, 1983a, p. 25)

Ao revelar essa "imagem do que os mais sábios saamaka sabem", Price adota uma cativante e singular estratégia de representação etnográfica. A maior parte do texto de First-Time é dividida em duas partes, ocupando as metades superior e inferior de cada página, funcionando como dois "canais" narrativos. No canal superior, lemos relatos saamaka de um "evento" específico; no inferior, comentários sobre tais eventos, por meio dos quais Price tenciona ao menos três funções. As duas primeiras - no que diz respeito à inteligibilidade dos relatos para aqueles não iniciados no discurso saamaka e ao sentido especial de cada evento para o informante saamaka que o profere - são bastante diretas, não é preciso nos ocuparmos delas aqui. A terceira função, entretanto, é conceitualmente a mais interessante e de fato a mais crucial para o cerne do argumento de Price: serve para introduzir "informação de fontes escritas contemporâneas aos eventos - cronologia, geografia e outros fatos" para "[...] trabalhar em direção a uma imagem do que 'realmente aconteceu', contra a qual podemos medir e dar conta do complexo processo de seleção usado pelos saamaka no que tange ao seu passado distante" (Price, 1983a, p. 39).

Essa, em suma, é a arrojada e inovadora estratégia etnográfica de First-Time. Ela conta uma história de continuidades entre o presente e um passado chamado escravidão. Sugerirei, entretanto, que essa é 
uma estratégia plausível apenas se aceitarmos a premissa conceitual (que passados são preserváveis e representáveis) e o pressuposto ideológico (que a tarefa especial de uma antropologia dos povos da diáspora africana consiste em provê-los de um aparato para corroborar passados) do seu objeto teórico alvo.

Existe no argumento de Price uma ambiguidade notável, que gira em torno do que podemos chamar de um programa de entendimento histórico do que se acredita estar em jogo ao compreender a consciência de um povo acerca de seu passado. Price nos conta que o discurso saamaka acerca de seu passado, da escravidão nas plantations e de sua luta contra ela, é "seletiva", e que o que é selecionado tem significado na estrutura das expectativas operando no presente. Entretanto, este passado seletivo, construído, não é examinado com o intuito de revelar as razões para seleções específicas, mas como forma de demonstrar a autenticidade verificável do conteúdo das afirmações saamaka sobre o passado. Para Price, o problema relevante erguido pelo caráter seletivo deste discurso não é a economia de significados na qual tal seleção opera. Ainda que ele aponte o caráter ideológico do conhecimento sobre os primeiros tempos, Price não o faz para abrir caminho para uma discussão formal neste registro. Exatidão referencial é sua preocupação principal. Assim, o problema antropológico que se apresenta não é, como poderia ter sido, nem o mapeamento ou a descrição das maneiras por meio das quais o passado é ideologicamente produzido e usado pelos saamaka na construção de suas tradições culturais oficiais e identidades singulares, nem as variadas maneiras como essas construções são negociadas, tornadas convenções, subvertidas, descritas novamente e assim por diante. Ao invés, o problema é determinar em que medida os eventos que foram selecionados de fato ocorreram, até que ponto trata-se de uma representação precisa do que realmente aconteceu.

Logicamente, tal estratégia conceitual pressupõe um aparato histórico/interpretativo independente dos relatos saamaka, capaz de identificar e representar "o que realmente aconteceu" nesse passado saamaka; e, que deve fazê-lo no intuito de fornecer representações históricas que operam como uma espécie de controle para a precisão das suas memórias saamaka sobre o passado. No texto de Price, este 
aparato é formado pelo arquivo de documentos coloniais neerlandeses sobre o período em pauta. Arquivo que, segue-se, não serve para ser "lido" - isto é, interrogado como uma densidade discursiva, uma configuração irredutível de política colonial e textualização ideológica -, mas para verificar as afirmações saamaka acerca de certos eventos. Apontar isso não é impugnar o uso de material de arquivo na pesquisa antropológica, mas divergir da visão que parece ser a de Price, a de que tanto os testemunhos orais de seus informantes saamaka quanto os textos escritos dos colonizadores neerlandeses são maneiras culturalmente diferentes, mas conceitualmente descomplicadas - de re-apresentar o passado no presente. ${ }^{18}$

A concepção de Price de consciência histórica, portanto, não é muito coerente. Contudo, as questões epistemológicas acerca de como adequadamente conhecer o passado saamaka, e de que tipo de provas serviriam para fundamentá-lo, são intrinsecamente menos importantes para mim aqui do que a questão dos pressupostos ideológicos que servem para assegurar a suposta autoridade de tais argumentos antropológicos acerca deste passado. Em minha leitura, é isso o que realmente está em jogo. Esses pressupostos ideológicos estão relacionados com o tipo de objeto antropológico construído a partir do afro-americano ou do afro-caribenho (ou, em todo caso, do Negro do Novo Mundo). Eu diria que ao menos um dos pressupostos ideológicos difusos por meio dos quais esse objeto teórico foi construído seria o de que os povos de ascendência africana no Novo Mundo necessitam de algo como a antropologia, uma ciência da cultura, para fornecer uma garantia fundacional de um passado autêntico.

Price visa demonstrar conclusivamente que um povo afroamericano de fato possui uma memória precisa de eventos passados. Para início de conversa, podemos perguntar por que necessitamos de tal demonstração? Quais são as condições ideológicas que a motivam? Ou, dizendo de outra forma, quais são as fontes que transmitem um significado especial ao ambicioso subtítulo da etnografia de Price - "a visão histórica de um povo afro-americano"? O que está implícito em sua alegação inclusiva é que, de alguma forma, a "visão histórica" dos saamaka deve ser tomada como esclarecedora da visão histórica 
dos povos afro-americanos como tal. Os saamaka, em suma, são uma espécie de metonímia antropológica, e devem ser entendidos como fornecendo a arena exemplar na qual se discute certas afirmações antropológicas sobre um domínio discursivo chamado de Afro-América. E aqui, penso, está o primeiro elemento da estrutura ideológica de FirstTime que precisamos levar em conta: sua localização na genealogia de um problema antropológico específico, isto é, o problema do africano no Novo Mundo.

First-Time é uma etnografia cativante, em parte por parecer ser uma refutação quase conclusiva da velha ideia antropológica acerca de suposta "atemporalidade" dos povos primitivos, sua falta de "consciência histórica". First-Time - assim como $\underline{\text { Ilongot Headhunting (Caça por }}$ Cabeças entre os Ilongot), de Renato Rosaldo - apresenta o argumento que esta ideia não seria nada além de preconceito antropológico (ou melhor, ocidental); Price faz essa afirmação de forma relativamente explícita. ${ }^{19}$ Entretanto, sugiro que o aparente poder do argumento de Price deriva de outra fonte, isto é, de um objetivo mais local: sua preocupação em deixar de lado a contumaz ideia de que os povos de ascendência africana no Novo Mundo sofrem de uma "falta de passado". ${ }^{20}$ Curiosamente, como a explicitação de tal objetivo é suprimida em First-Time, o mesmo aparece como o assunto central de um curto ensaio sobre a "consciência histórica caribenha" publicado pouco depois, que passou praticamente despercebido ${ }^{21}$. Nesse ensaio, Price elege como alvo aquilo que chama de "negação da história" aos descendentes de africanos no Novo Mundo - a "vanguarda para aquelas pessoas para quem a história foi tão frequentemente negada" (Price, 1985, p. 24). Diversos escritores das Índias Ocidentais - em particular V. S. Naipaul, Orlando Patterson e Derek Walcott - são escolhidos para uma crítica afiada. Tais escritores, na avaliação de Price, são cúmplices de um raciocínio (uma "ilusão burguesa, uma função de nosso [?] próprio etnocentrismo") que afirma que "os povos caribenhos sofrem de uma profunda falta de consciência histórica, que eles não sabem (ou não se importam com) quase nada acerca dos seus próprios - complexos e amiúde infelizes - passados" (Price, 1985, p. 25). Um pouco depois, ele nos conta que "a prova mais forte que consegui coligir contra esta 
noção de afro-caribenhos sem passado está, sem dúvida, contida em First-Time. O livro desvela uma visão do passado com extraordinária relevância para os saamaka do presente" (Price, 1985, p. 27).

Não entrarei aqui na interessante questão da leitura (errônea, penso) do imaginário histórico da literatura das Índias Ocidentais. Deixo isso para outros. ${ }^{22}$ Minha preocupação aqui é indicar algo da localização ideológica de First-Time. Assim, com base na verificação de uma consciência autêntica de um passado no qual a escravidão forma o momento gerativo referencial, o livro se coloca contra a difusa pressuposição de "falta de passado" de povos de ascendência africana no Novo Mundo. Singularmente situados para isso, os saamaka funcionam como um palco exemplar no qual podem ser apresentados, de forma nítida, tanto o problema dos passados das diásporas afro-americanas quanto sua resolução antropológica. A seguinte questão se coloca: quais são as fontes históricas dessa ideia de que o problema teórico posto pela existência de povos de ascendência africana no Novo Mundo consiste em corroborar seu passado? É a essa questão que volto a minha atenção agora.

\section{Problema Antropológico do "Negro do Novo Mundo"}

O problema antropológico dos povos de ascendência africana no Novo Mundo foi constituído pela antropologia cultural americana mais do que pela antropologia social britânica, e ele carrega as marcas distintivas desta origem. Se a antropologia social britânica foi criticada (amiúde justamente) por sua relação com o império britânico e com as fontes, estruturas e representações do domínio colonial, a antropologia cultural americana teve a sorte de aparecer sob uma luz muito menos desagradável. Talvez com razão. Franz Boas (a principal figura na fundação da antropologia profissional nos EUA) não apenas abriu caminhos para um conceito de "cultura" segundo o qual as práticas de todos os povos deveriam ser encaradas em seus próprios termos, como também era um franco crítico do racismo e da discriminação étnica - ver Boas (1974a), Stocking (1979), Hyatt (1985). Contudo, tal distinção não elimina a necessidade de examinar os determinantes ideológicos do discurso da antropologia cultural americana. A questão 
a ser abordada aqui não é aquela importante, mas tão repetida, acerca da escassez de pesquisas antropológicas adequadas sobre a cultura afro-americana - ver Willis (1970) e Szwed (1974), e sim a de como esse objeto, a Afro-América, veio a ser constituído nos textos desse discurso cultural.

Richard Price não foi o primeiro antropólogo americano a estudar os saamaka. Nem tampouco o primeiro a perceber que os saamaka oferecem, de alguma maneira, a chave para o problema antropológico do africano no Novo Mundo. Ele foi precedido em ambos os aspectos por Melville J. Herskovits ${ }^{23}$. Aluno de Franz Boas (e, neste aspecto, muito influenciado por ele), Herskovits, talvez mais do que qualquer outra pessoa, ajudou a estabelecer o "Negro do Novo Mundo" como um problema antropológico positivo, ou seja, um problema visível e distinto de "história" e "cultura"24.

A contribuição de Herskovits para a formação de uma antropologia do "Negro do Novo Mundo" é inseparável de dois outros debates. O primeiro é o discurso mais amplo que construiu o negro como um problema social de certo tipo; o outro é a discussão acerca das categorias conceituais da nascente "ciência da cultura" que formulava o Negro do Novo Mundo como um problema teórico específico. Ainda que seja impossível aqui delinear a complexidade histórica dessas condições ideológicas prévias, é necessário apontar ao menos alguns aspectos que foram cruciais para a problemática conceitual na qual Herskovits inseriu-se.

Nos anos que antecederam a Primeira Guerra Mundial, a "questão do negro", em seus aspectos sociais e ideológicos, girava em torno da possibilidade de considerar o negro como candidato para a plena cidadania no corpo político americano ${ }^{25}$. O negro poderia ser assimilado aos valores e ao ethos da sociedade americana? Ou havia algo de distintivo no negro que impedia ou de alguma maneira qualificava seriamente a assimilação? De um modo ou outro, essa questão da ambígua identidade do negro girava em torno da ideia, difusa no início do século XX, de que os negros formavam um povo sem passado significativo, e portanto um povo sem contribuição notável à civilização - sem cultura, no sentido arnoldiano ${ }^{26}$. Tal ideia era ligada a duas outras imagens: a da 
escravidão como uma instituição que havia apagado completamente as identidades africanas dos escravos e a da África como um lugar escuro e selvagem (Fredrickson, 1971). Enquadrados pela tradição evolucionista guiada por Herbert Spencer nas ciências sociais deste período, muitos aceitavam tais pressupostos e imagens (Stocking, 1968). Essas questões certamente formaram parte da atmosfera ideológica em meio a qual emergiu a antropologia americana como disciplina profissional; ao mesmo tempo, pode-se dizer que também pertenciam a um horizonte ideológico no qual a nova antropologia definia a si mesma e a tarefa distintiva de seu conceito seminal: a cultura.

Entre o final da década de 1880 e a virada do século, Boas havia estabelecido o que podemos chamar de uma estratégia de interrogação cética (Krupat, 1988) dos dois "ramos" então existentes na antropologia: o "biológico" e o "psicológico". Ao fazê-lo, demonstrou o caráter pouco convincente dos argumentos de ambos (no tocante à questão da habilidade mental das diferentes raças, por um lado e, por outro, à reconstrução histórica dos estágios de desenvolvimento social da "humanidade"), bem como a sobredeterminação ideológica das pretensões de superioridade ocidentais nelas contidas. Tal interrogação teria uma série de efeitos conceituais importantes, entre eles: o deslocamento de "raça" como chave explicativa da diferença; a reavaliação anti-hierárquica dessa diferença como "cultura" e a reconfiguração da "ciência" antropológica para o estudo histórico e etnográfico de instâncias particulares - isto é, "culturais" - de diferença.

Ainda mais pertinente para nossa preocupação com as condições conceituais prévias da antropologia do "Negro do Novo Mundo", Boas argumentou que essas instâncias culturais devem ser entendidas analiticamente em termos da integração - psicológica e histórica - de "elementos" (isto é, partes) em "todos" (isto é, conjuntos). Culturas são distintas (e, portanto, válidas) em virtude do crescimento de uma unidade interna (um "estilo" ou "ethos") composta de traços transmitidos ou difundidos historicamente de local para local e de grupo para grupo. A cultura de qualquer tribo, sustentou Boas (1974b, p. 278), 
[...] por mais primitiva que seja, só pode ser plenamente explicada quando levamos em consideração o seu desenvolvimento interno e sua relação com a cultura de seus vizinhos próximos e distantes, buscando o efeito que eles possam ter exercido.

Não apenas todas as culturas seriam válidas - a europeia não mais que a africana - mas cada uma traria uma relação distinta com os passados dos quais derivam. Sob a luz dessa reformulação radical (para seu tempo) da questão da diferença, não surpreende que Boas tenha respondido à imagem racista da época da cultura negra com a tentativa de aproximá-la à representação - antropologicamente reabilitada - do passado africano. À definição boasiana de diferença "cultural" seguia-se que qualquer avaliação da Afro-América deveria considerar "sua relação com a cultura de seus vizinhos próximos e distantes". Foi o que Boas buscou demonstrar na Universidade de Atlanta em 1906, quando "lembrou" seu público de formandos negros do passado de "realizações" culturais de seus antepassados africanos (Boas, 1974a).

O mais notável nas observações de Boas acerca da cultura negra, entretanto, não foi sua força referencial, mas o fato delas não reivindicarem uma "africanidade" essencial para a cultura afroamericana. Para Boas, a cultura do "Negro do Novo Mundo" não está dada numa relação contínua com o passado africano etno-histórico que ele autorizadamente evoca. O "gênio" ou geist dos afro-americanos, aquela característica que dá às suas variadas práticas a "totalidade" ou "integridade" que Boas reivindica para a "cultura", não é atribuída de nenhuma forma analiticamente saliente a esta África evocada. O que essa África etnologicamente reabilitada faz é dar suporte a um passado que pertence ao negro apenas como fonte potencial de inspiração, algo que poderia ser alvo de um confiante olhar nostálgico por parte de jovens intelectuais afro-americanos, como aqueles para os quais Boas discursava em Atlanta, enquanto se esforçavam frente ao duro (e, como Boas sem dúvida sabia, real) trabalho de elevação racial. É possível que tal atitude refletisse o teor cauteloso e assimilacionista da política culta, de brancos e negros, na América liberal dos anos 
pré-guerra - a confiança no "maravilhoso poder de mistura [de] nossa nação", como coloca Boas (1974c, p. 202). De fato, esse era um tema politicamente delicado: afirmar a especificidade dos afro-americanos num tempo em que a diferença ainda era discutida em termos raciais seria dar combustível aos segregacionistas, para os quais os negros eram diferentes ao ponto de serem inassimiláveis. Ainda assim, a evocação etnológica da África por Boas foi, à sua maneira, um momento profundamente significativo. Não é difícil entender o entusiasmo de Du Bois pois, na declaração do antropólogo branco, o enigmático signo de nossa memória racial - os metafóricos Egito e Etiópia do recém publicado As Almas da Gente Negra, no qual "[...] a sombra de um poderoso passado negro adeja no conto de Etiópia, a Sombria, e do Egito, a Esfinge [...]" (Du Bois, 1989, p. 3) - recebia fundamentos e garantias tangíveis (ou seja, científicos).

As condições da relação entre a "cultura" boasiana e a AfroAmérica mudaram consideravelmente após a Primeira Guerra Mundial, de modo que a antropologia especificaria mais precisamente este ilusivo fundamento (a África) e abordaria a questão da garantia científica do orgulho racial afro-americano de maneira mais audaciosa e direta. Ao menos duas foram as razões para essa mudança, uma relacionada às condições da ideologia racial frente à emergência de um "Novo" Negro (Locke, 1925); ${ }^{27}$ outra ao desenvolvimento do que George Stocking chamou o período "clássico" da antropologia americana moderna (Stocking, 1989).

Ao longo dos anos de guerra as condições políticas da ideologia racial (como muitas outras coisas na textura da vida social nos EUA) alteraram-se tanto que o assimilacionismo no estilo "décimo talentoso" 28 foi crescentemente posto em questão por um nacionalismo cultural mais vigoroso e menos aberto a concessões (Huggins, 1976). Uma consequência foi que, por todo o leque de posições ideológicas afroamericanas daquela época - dos discípulos de Marcus Garvey de classe operária aos organizadores intelectuais do pan-africanismo, passando pelos artistas e literatos do Renascimento do Harlem - pessoas de ascendência africana passaram a reivindicar, valendo-se de distintas entonações, um passado chamado África, colocando-o no primeiro plano 
de suas afirmações comunitárias e de identidade cultural ${ }^{29}$. Penso que algo desta atmosfera generalizada está presente na contribuição do ensaísta e bibliófilo Arthur Schomburg à antologia de Alain Locke, The

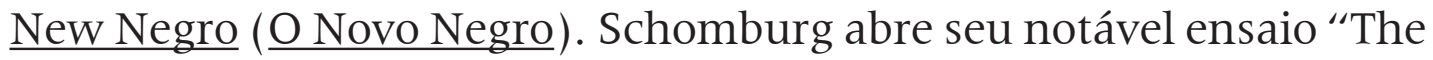
Negro Digs Up his Past" ("O Negro Desenterra o seu Passado") sugerindo que os afro-americanos não poderiam adotar a ideia emersoniana ${ }^{30}$ de que seria "desnecessário ter um passado" nos Estados Unidos, e encerra-o com a inflamada afirmação de que, ainda que o negro tenha sido difamado como "um homem sem história por ter sido considerado um homem sem qualquer cultura digna", ele agora começava a ver

[...] a si mesmo a partir de uma origem resgatada, numa perspectiva que dará ampla margem para o orgulho e para o respeito próprio, fazendo com que a história concedalhe os mesmos valores que o valioso passado de qualquer povo proporciona. (Schomburg, 1925, p. 237)

Ainda assim, pelo menos a partir da referência que o bem informado Schomburg evoca - as evidências da etnologia africana - essa origem ainda era vaga e indefinida. Como o finado Nathan Huggins coloca em sua brilhante discussão da política cultural do Harlem dos anos 1920: “todos pareciam saber, ou sentir, que a África deveria significar algo para a raça, que deveria haver alguma memória racial que unia os homens negros, [entretanto,] a ambiguidade e a dúvida sempre deixaram a questão mal resolvida" (Huggins, 1979, p. 80-81).

O espaço ideológico no qual Melville Herskovits adentra - depois de receber seu diploma na Columbia University em 1923, sob a orientação de Franz Boas - era caracterizado por um complexo de posições no qual o passado e sua figura indicadora, a África, desempenhavam um papel crítico na articulação de uma relação positiva entre ser, de alguma forma, tanto distintivamente negro quanto americano. Certamente, nessas novas circunstâncias ideológicas, a questão sobre "como o orgulho racial afro-americano poderia ser colocado sobre uma base científica" deve ter surgido para um aluno de Boas tal qual Herskovits (que tinha muitos amigos importantes no Harlem ${ }^{31}$ ). E aparecido demandando uma resposta diferente ou, no mínimo, menos ambígua, do que aquela dada por Boas duas décadas antes. E certamente a 
autoconsciência científica emergente naqueles anos na disciplina fez com que tal resposta parecesse possível.

Em meados dos anos 1920, a profissionalização da antropologia americana começava a dar a seus praticantes um ar de confiança intelectual e autoridade científica. Afinal, a disciplina agora podia ostentar seu próprio "laboratório" 32 (como fortemente demonstrado pela pesquisa de Margaret Mead no Pacífico Sul) e, nas distintas abordagens de Mead, Ruth Benedict e Robert Redfield, a disciplina empregava um aparato metodológico cada vez mais sofisticado e otimizado. Porém, o desenvolvimento deste período mais pertinente às nossas preocupações com a formação de uma antropologia do Negro do Novo Mundo foi a elaboração do conceito de "aculturação". Já entrevista nas ideias de Boas sobre a disseminação e integração histórica de elementos culturais, ${ }^{33}$ na virada da década de 1930 a aculturação começa a conquistar distinção conceitual e apelo acadêmico. Delineado programaticamente por Redfield, Ralph Linton e Herskovits, em seu memorando para o Conselho de Pesquisa em Ciências Sociais dos Estados Unidos, o conceito foi nitidamente distinguido de outros conceitos relacionados, pertencentes ao léxico boasiano, como "mudança cultural", "assimilação" e "difusão" (Redfield; Linton; Herskovits, 1936). Recebeu uma definição precisa e um rigor metodológico até então ausentes. O estudo da aculturação deveria ser guiado por uma cuidadosa identificação de "traços" e pelo problema da seleção, determinação e integração desses "traços" em outros padrões. Tal identificação e classificação seria então combinada com uma investigação dos "mecanismos psicológicos" de seleção e integração.

Essa visão retinha a fundadora ideia boasiana de que a cultura seria constituída de elementos ou unidades essenciais, quantificáveis, que se integrariam em um todo psicologicamente significativo, capaz de ser representado de modo não problemático em textos etnográficos. A visão ajuntava a esta base um programa de investigação mais positivista: um aparato metodológico para sistematicamente identificar e classificar tais traços, para rastrear suas origens e fontes autênticas, e para conceitualizar a maneira como se encaixariam em uma totalidade cultural essencial. Assim concebida, a antropologia da aculturação 
era mais cientificamente crível. Ademais, se a antropologia boasiana ainda retinha (como retivera de forma mais urgente antes da guerra) a conviç̧ão socialmente consciente de que essa ciência poderia ter o efeito humanista prático de inspirar orgulho racial aos afro-americanos, isso agora poderia ser levado a cabo de uma maneira menos especulativa e mais empiricamente robusta. Assim, sugiro que a contribuição seminal de Herskovits à antropologia do Negro do Novo Mundo pode ser lida como uma tentativa de demonstrar como o negro poderia de fato ser tanto distintivamente negro quanto americano - e de fazê-lo no contexto de uma nova e mais confiante ciência da cultura (Jackson, 1986).

No começo da década de 1920, Herskovits ainda mantinha a visão assimilacionista - bastante comum entre liberais americanos brancos - de que o negro não era culturalmente distinto, era de fato tão americano quanto qualquer um: “o mesmo padrão, mas em um matiz diferente!", como celebremente colocou em sua contribuição ao The New Negro (Herskovits, 1925, p. 353). Até 1927 ele ainda falava dos afro-americanos como pessoas "da mais diversa origem racial, mas vivendo a vida de americanos brancos" (Herskovits, 1927, p. 224). Porém, ao fim dessa decisiva década de expressão cultural negra, Herskovits, profundamente influenciado pela eloquente e assertiva onda de consciência negra, inverteu completamente sua posição e começou a delinear as ideias pelas quais se tornaria mais conhecido. ${ }^{34}$ Baseado em numerosos estudos etnográficos (Life in a Haitian Valley [ $\underline{\text { A Vida em }}$ um Vale Haitiano] (1971b [1937]) talvez seja o mais admirado dentre eles) e em obras de reconfiguração conceitual (das quais The Myth of the Negro Past [O Mito do Passado Negro] ( 1941) é sem dúvida a mais conhecida) que, juntos, constituem a pedra angular da antropologia das diásporas africanas do Novo Mundo, Herskovits propôs demonstrar não apenas que o Negro do Novo Mundo era culturalmente distinto, mas também que sua distintividade devia-se precisamente à sua herança africana autêntica.

Significativamente, o primeiro lugar para onde Herskovits foi, em seu empreendimento de desvelar a africanidade distintiva da cultura afro-americana, foi o Suriname, então colônia neerlandesa, que visitou 
(com sua esposa Frances) nos verões de 1928 e 1929. Esboçando retrospectivamente o curso de seus interesses sucessivos enquanto escreviam Rebel Destiny: Among the Bush Negroes of Dutch Guiana (Destino Rebelde: Entre os Negros do Mato da Guiana Neerlandesa) - sua popular descrição da vida saamaka na década de 1920 - o casal Herskovits escreveu:

Tudo começou em 1923, com o exame do cruzamento entre negros e brancos nos Estados Unidos. À medida que este trabalho progredia, tornou-se evidente que o problema demandava mais conhecimento do que então disponível acerca das origens dos escravos que compõem a linhagem negra dos negros americanos. Tal conhecimento, ao qual os documentos históricos não nos davam acesso, deveria, portanto, ser buscado na comparação com as culturas negras no Novo Mundo e na África. (Herskovits; Herskovits, 1971a [1934], p. vii-ix)

Sob essa concepção de que o entendimento de práticas culturais contemporâneas requer conhecimento de suas origens autênticas, o negro norte-americano (a partir de quem o problema como tal fora formulado) permanecia sendo uma espécie de enigma. Assim, tornou-se necessário - ou, ao menos, parecia necessário - ir alhures à busca das origens do negro norte-americano. Já no início dos anos 1930, Herskovits construía a narrativa metonímica que uniria a Afro-América em um todo, diferençável internamente pela mensuração das proximidades com a África.

Em seu estudo do Suriname neerlandês, o casal Herskovits adotou uma estratégia comparativa, estudando tanto os saamaka do interior quanto os afro-surinameses ${ }^{35}$ urbanos da capital Paramaribo. As premissas são óbvias: os afro-surinameses da cidade, em virtude de sua longa associação com a cultura europeia, tinham menos probabilidade de terem retido tantos traços africanos quanto os saamaka do "mato". E, de fato, o casal Herskovits descobriu que a diferença crítica entre mato e cidade era que "o mato é a África do século XVII" (Herskovits; Herskovits, 1971a, p. x). De maneira mais direta, escrevem:

A importância dos negros do mato para o pesquisador das culturas negras, portanto, é que eles vivem e pensam 
hoje como seus ancestrais que se estabeleceram naquelas matas, o que significa que vivem e pensam de uma maneira muito similar aos negros que foram trazidos para outras partes do Novo Mundo, tornando-se os ancestrais dos atuais negros das Américas. (Herskovits; Herskovits, 1971a, p. xii)

Na década de 1930, depois do retorno de Herskovits do Suriname, ele elaborou o que chamou de "escala de intensidade de africanismos", que serviu de base para defender a possibilidade de mensurar o grau real de retenção de elementos da cultura africana pelo negro no Novo Mundo.

É bastante possível, com base em nosso atual conhecimento, fazer uma espécie de tabela indicando a medida de retenção de africanismos no comportamento cultural dos descendentes de africanos trazidos ao Novo Mundo. Se considerarmos a intensidade de elementos culturais africanos em várias regiões ao norte do Brasil [...] podemos dizer que, depois da própria África, são os negros do mato do Suriname que exibem a civilização mais africana [...] Próximos a eles em nossa escala estariam seus vizinhos negros das planícies costeiras das Guianas, que, apesar de séculos de associação com os brancos, retiveram uma quantidade espantosa de suas tradições aborígenes africanas, muitas das quais se combinam de modo curioso com as tradições do grupo dominante. (Herskovits, 1930, p. 149)

E assim por diante, até que "finalmente, encontremos um grupo no qual, para todos os efeitos, não resta nada da tradição africana, constituído de pessoas com variáveis graus do tipo físico negroide que se diferenciam de seus vizinhos brancos tão somente pelo fato de terem mais pigmentação em suas peles" (Herskovits, 1930, p. 150). Dos negros do mato do Suriname numa ponta da "escala de intensidade de africanismos" até os negros norte-americanos na outra, Herskovits reconstruía a medida precisa do que o Negro do Novo Mundo retivera do velho no novo, do passado no presente.

Parece correto afirmar que este é o momento inaugural de uma persistente problemática antropológica. O Negro do Novo Mundo foi ideologicamente constituído, por um discurso oitocentista dominador 
e racista, como uma figura sem passado determinado e, logo, sem seu suposto corolário, uma cultura distintiva. Em meados da década de 1920, os contradiscursos negros articulavam uma política de identidade radical e, ao fazê-lo, reivindicavam uma herança africana ativa, reivindicação marcante e impossível de ser ignorada. Assim, no terreno conceitual estabelecido pelas categorias boasianas de cultura, a tarefa que se apresentava à nova antropologia era mostrar, da maneira mais cientificamente conclusiva possível, que o Negro do Novo Mundo de fato tinha tanto um passado determinado quanto uma cultura distintiva. Já que se assumia que a África era a origem cultural autêntica da diáspora negra, Herskovits propôs demonstrar, por meio de um esforço de corroboração, os vestígios deste passado nos traços culturais de sociedades negras contemporâneas. Os saamaka, então, forneceriam a possibilidade única de demonstrá-lo.

Richard Price, é verdade, não se preocupa com retenções culturais como tais. Ele não tenta demonstrar a existência de traços autênticos de um passado chamado África ainda presentes no Novo Mundo. ${ }^{36}$ No meio-tempo, o conceito antropológico de cultura afastou-se da base dura e positivista dos "traços", rumo a um mais semiótico campo de símbolos e "consciência". ${ }^{37}$ Além disso, as condições ideológicas desde a década de 1960 não mais exigiam que o Negro do Novo Mundo fosse colocado na vizinhança imediata da figura reabilitada da África (ou pelo menos não da mesma maneira como exigiram nas primeiras décadas do século XX). Ao invés disso, Price quer mostrar que há uma "memória" ou "consciência" autêntica de um passado chamado escravidão. Mas não é difícil perceber que, apesar da aparente diferença, tanto Herskovits quanto Price partilham de uma premissa fundamental no que tange à história e à cultura dos povos de ascendência africana no Novo Mundo: a premissa de que tal história e cultura devem ser discutidas nos termos de uma noção de um passado autêntico, que persiste no presente (qualquer que seja seu nome ou modalidade) e, além disso, que este persistente passado pode ser conclusivamente demonstrado por meio de um caso etnográfico exemplar, os saamaka do Suriname - supostamente o povo mais próximo daquele passado. 


\section{Entre aquele Evento e esta Memória: Tradição}

Gostaria de propor que tentemos mudar de vez essa problemática antropológica, essa contínua preocupação com a corroboração ou verificação de passados autênticos. A questão nada tem a ver com o apagar da antropologia dos povos de ascendência africana no Novo Mundo as figuras da África ou da escravidão (ou mesmo da ressoante narrativa de continuidade que as incorpora). O que proponho é sua realocação teórica. Entre aquele evento (África ou escravidão) e esta memória, estende-se um complexo campo discursivo que podemos produtivamente chamar de "tradição": ${ }^{38}$ um campo diversificado de discurso cuja unidade, tal como existe, reside não em traços antropologicamente validados, e sim em sua construção em torno de um distinto grupo de tropos ou figuras que, juntas, efetuam tarefas retóricas bastante específicas.

A primeira e mais óbvia das tarefas da tradição é assegurar conexões entre um passado, um presente e um futuro. No campo teórico ocupado pelo trabalho de Herskovits e Price, as figuras da África e da escravidão circulam como presenças autênticas, que a antropologia deveria tornar legíveis nas práticas ou consciências dos descendentes de africanos ou escravos. O projeto que recomendo estaria preocupado com os seguintes tipos de questões: de quais maneiras a África e a escravidão são empregadas por povos de ascendência africana no Novo Mundo em suas construções narrativas acerca de relações entre passados, presentes e futuros? Em cada um dos variados casos, quais as características salientes por meio das quais se inscrevem cada uma dessas figuras? Nas variadas instâncias em que essas figuras são postas em jogo, que e trabalho retórico (ou, se preferir, ideológico) elas são levadas a performar? Por exemplo: os "primeiros tempos" dos rastafáris jamaicanos (e eles de fato falam de "primeiros tempos"), como o dos saamaka, gira em torno da figura da escravidão, mas é provavelmente inscrito com um conjunto distinto de investimentos ideológicos, refletindo suas condições históricas e políticas específicas. Estaria menos em jogo aqui ser ou não possível mensurar o quanto essa comunidade diaspórica de rastafáris retém uma memória precisa de qualquer evento pré-emancipação verificável, e mais as maneiras 
por meio das quais essa figura, a escravidão (e as figuras metafórica e metonimicamente a ela ligadas), permite (ou previne) o estabelecimento de posições num campo cultural e político.

Porém, as tradições culturais não apenas possuem autorias, elas também são autorizadas. Não apenas tornam algo inteligível, tornam legítimo. Assim, segunda tarefa da tradição passa por assegurar o que podemos chamar de uma comunidade distintiva de adeptos. Que espaço a África e a escravidão ocupam na economia política do discurso local? A que tipo de autoridade recorrem? De que tipo de público buscam apoio? Quais são as condições - discursivas e não discursivas - de recepção que facilitam sua capacidade de persuasão? Tomemos, por exemplo, os usos da figura África por Arthur Schomburg (o bibliófilo) e Marcus Garvey (o líder das massas), ou ainda seus usos nos versos de um cantor de calipso, de um lado, ou na retórica política de um Michael Manley ${ }^{39}$, de outro. O ponto é que essa figura pode ter diferentes usos políticos, diferentes modos de autorização, pode ser endereçada a diferentes públicos, e ainda assim pertencer a uma tradição distinta, posto que uma mesma figura está sendo usada na construção de uma relação entre passados e presentes.

A terceira tarefa da tradição é conectar narrativas do passado às narrativas de identidade. Pois é claro que a tradição busca não somente fazer o passado inteligível e legítimo, mas também instruir, isto é, ativamente cultivar as virtudes que valoriza. Como que as figuras da África e da escravidão são empregadas na confecção de virtudes, disposições, modos de abordagem e estilos específicos (de vestimenta, fala, música, movimentos corporais)? Em outras palavras, como que essas figuras participam das técnicas por meio das quais se constroem e efetuam formas apropriadas de corpo e de self?

Parece-me que tais perguntas permitem questões mais teoricamente interessantes sobre passados no presente. Pode-se notar também, por um lado, que não são perguntas essencialistas, já que não pressupõem a presença total ou parcial de uma África ou de uma escravidão que necessitariam apenas passar pela grade interpretativa da antropologia para serem reconhecidas ou apreciadas pelo que são. Mas, por outro, tampouco são perguntas antiessencialistas, já que não afirmam não 
haver real continuidade entre a África, ou a escravidão, e o presente, não afirmam que estes são apenas significados vazios. De fato, essas perguntas não buscam reivindicar coisa alguma acerca do status ontológico definitivo da África ou da escravidão nas culturas do Novo Mundo, e, portanto não colocam a tarefa da investigação antropológica como sendo a de tentar representar de maneira precisa - ou negar - a proximidade entre o passado e o presente. Ao mesmo tempo, essas perguntas afirmam que povos de ascendência africana no Novo Mundo de fato fazem da África e da escravidão uma presença profunda em seus mundos culturais, e buscam descrever a tradição de discurso da qual participam, as redes locais de poder e saber nas quais são empregadas, os tipos de identidades que servem para moldar.

\section{Notas}

1 Original: SCOTT, David. That Event, This Memory: Notes on the Anthropology of African Diasporas in the New World. Diaspora: A Journal of Transnational Studies, [S.l.], v. 1, n. 3, p. 261-284, 1991. Por permitirem a presente tradução, agradecemos a David Scott, à University of Toronto Press (em particular Meaghan Lloyd) e ao periódico Diaspora (em particular Khachig Tölölyan) [N. dos T.].

2 Versões deste artigo foram lidas na University of California, em Santa Cruz; na Northeastern University, em Boston; e na Rice University, em Houston. Comentários em cada uma dessas ocasiões contribuíram para o texto. Agradeço especialmente Elizabeth Eames por suas penetrantes críticas a uma versão anterior do trabalho, e a Herman Gray, com quem discuti muitas das ideias aqui presentes.

3 Sobre algumas escolhas de tradução: "passagem do meio" é tradução usual para o termo corrente na historiografia inglesa, "Middle Passage", que se refere à travessia do Atlântico por meio dos navios negreiros. Seguindo a literatura antropológica e historiográfica brasileira pertinente, optou-se não traduzir o conceito "plantation", que designa o modelo de produção agropecuária, desenvolvido no século XVI, que envolve monocultura voltada para a exportação, latifúndio e trabalho escravo ou de contrato. Por fim, "New World Negro" será traduzido por "Negro do Novo Mundo", ao invés de "Negro no Novo Mundo", como ocorre em diversas traduções brasileiras do termo, escolha que nos permite marcar nuances de sentido quando o autor refere-se a "povos de ascendência africana no Novo Mundo", ou expressões similares [N. dos T.].

4 Práticas e lutas que podem ser, é claro, acadêmicas ou leigas, mas tal distinção pode ser suspensa para os propósitos deste ensaio.

5 Há uma história contemporânea - de muitos modos uma história contra-hegemônica - de acordo com a qual a antropologia é central no desfazer da narrativa-chave hegemônica ocidental. Nessa história, a antropologia, como discurso da cultura, é contraposta à filosofia, o discurso judicante da Razão. A disciplina é assim vista como um modo potencial de empoderar Outras racionalidades - isto é, cultura(s) - contra a Razão (ou, ao menos, contra a Razão como uma forma distinta de 
conhecimento cultural, a forma do Ocidente Iluminista e pós-Iluminista). Mas talvez falte reconhecer de que maneira a "cultura" em si poderia simplesmente substituir a Razão como uma nova fundação autêntica - o solo, por assim dizer de outra ontologia.

6 O texto desta palestra foi reproduzido em Boas (1974a). Os efeitos da fala sobre o jovem Du Bois são hoje bem conhecidos. Em uma famosa passagem do prefácio de seu livro Black Folk, Then and Now (Gente Negra, Passado e Presente), ele escreve: "Franz Boas veio à Atlanta University, onde eu lecionava história, em 1906, e disse a uma turma de formandos: 'vocês não precisam ter vergonha de seu passado africano', e depois contou a história de mil anos dos reinos negros ao sul do Saara. Fiquei atônito, sem palavras. Nunca ouvira falado nada daquilo, e dali em diante comecei a perceber o quanto [...] o silêncio e o abandono [...] podem fazer a verdade desaparecer completamente ou [...] ser distorcida inconscientemente." (1939, p. vii).

7 Penso ser importante insistir nesta distinção. Pois, note-se que o que a antropologia constrói é um objeto teórico, não uma identidade cultural (exceto na medida em que a antropologia torna-se hoje crucial na identidade cultural do Ocidente [ver McGrane, 1989]). Outra tarefa possível poderia ser examinar as maneiras por meio das quais o objeto antropológico é apropriado por povos de ascendência africana no Novo Mundo, para seus diversos objetivos.

8 Há ao menos duas possíveis interpretações para o hífen em "re-presentable" ("re-presentável") e termos derivados, ao longo do texto. Talvez o autor faça uma afirmação semiótica de que toda representação é uma nova apresentação, isto é, não há prática discursiva ou representativa que prescinda de mediação diferenciante. Ou, talvez, faça um jogo de palavras entre "representable" ("representável", no sentido de poder ser representado) e "presentable" ("apresentável", no sentido de ter boa apresentação, ser respeitável, descente, conveniente, tolerável) [N. dos T.].

9 A bibliografia em português traduziu "saramaka" por "saramakas", "saramacás" ou "saramacanos". Manteremos aqui a grafia hoje utilizada na própria língua saamaka, que omite o erre, seguindo a pronúncia nativa. A palavra - paroxítona - não será pluralizada por ser o plural em saamaka marcado por modificadores nominais e não por sufixos. Similarmente, "djuka" (infra) seguirá a grafia hoje corrente, "ndyuka" [N. dos T.].

${ }^{10}$ Em um recente comentário sobre teoria antropológica, Arjun Appadurai (1986) argumentou elucidativamente que a antropologia não problematiza suficientemente a relação entre local e teoria, argumento que eu apoio e gostaria de elaborar.

11 Os saamaka usam, para se referir aos eventos mais antigos de sua história, os termos "fesiten" (literalmente, "o(s) tempo(s) da frente" ou simplesmente "passado") e "fosuten" (literalmente, "primeiros tempos"). Seguindo a escolha de Price, que traduz ambas expressões por "first-time", optamos por "primeiros tempos". Mantivemos a expressão "First-Time" em inglês apenas para o título do livro, até hoje sem tradução para o português [N. dos T.].

12 Em uma discussão acerca dos possíveis caminhos abertos para uma antropologia pós-modernista, James Clifford escreveu que First-Time “[...] é prova de que a aguda autoconsciência política e epistemológica não necessariamente leva ao ensimesmamento etnográfico, ou à conclusão de que é impossível saber qualquer coisa sobre qualquer outro povo" (Clifford, 1986, p. 7). Ver também Marcus e Fischer (1986).

${ }^{13}$ De acordo com a última estimativa de Price (2013), seriam hoje cerca de 90.000 [N. dos T.]. 
14 "A palavra inglesa maroon", escreve Price (1983a, p. x), "[...] deriva do espanhol cimarrón, um termo usado originalmente em Hispaniola para se referir ao gado doméstico que fugira para as montanhas. No início do século XVI já era usado em colônias de plantation pelas Américas para designar escravos que com êxito escaparam do cativeiro".

15 Aqui uma constelação de termos complexifica a tradução. Diversas palavras foram utilizadas para nomear essas comunidades, que em verdade são seis: além das citadas, há ainda os matawai e os pamaka. Optamos manter "maroon" no original em inglês, ao invés de traduzir pelo similar "quilombola", a fim de sublinhar as especificidades da experiência dessas comunidades do Suriname e da Guiana Francesa, importantes para o argumento de Price (e, portanto para a crítica de Scott). O termo de origem espanhola, "maroon", e suas versões hoje correntes na bibliografia em línguas inglesa, francesa e neerlandesa, substituem o termo "Bush Negroes" (literalmente "negros do mato"), usado na época de Herskovits. Essa expressão traduz literalmente os termos que essas comunidades utilizam para falar de si mesmas ("businenge" e similares), mas, como em línguas europeias hoje soam politicamente incorretas, tal forma caiu em desuso na academia. Utilizamos "negro do mato" apenas para traduzir as palavras de Herskovits. Morton C. Kahn (nota 22, infra) utilizava o termo "Djuka", uma corruptela do etnônimo de um dos seis grupos (ndyuka), para se referir a todos os povos maroons do Suriname. Ainda que tal termo - mais frequente no início do século passado, mas ainda comum na Guiana e em Paramaribo - seja considerado derrogatório, mantivemos o uso de Kahn. Note-se que nossas escolhas buscaram seguir a função conceitual que assume, na pena de cada autor, a nomeação do conjunto dessas seis comunidades. O objetivo não foi a padronização. Algumas traduções lusófonas mais antigas verteram "maroon" em "marrão" e "Bush Negro" em "bosh", mas como tais opções nunca se estabeleceram, serão deixadas de lado [N. dos T.].

16 Para um discussão acerca da "urdidura de tropos" ("tropic emplotment") na reconstrução histórica, ver White (1978).

17 Algo próximo ao "tempo dos japoneses" no discurso dos Ilongot das Filipinas, estudados por Renato Rosaldo. De uma maneira mais matizada e teoricamente reflexiva, Rosaldo compartilha com Price alguns desses conceitos deficientes (Rosaldo, 1980a; 1980b).

18 Parte da preocupação de Price é advertir-nos contra imposições acríticas de pressupostos ocidentais acerca da história (supostamente, a ideia de que a história é essencialmente composta de documentos escritos), e encorajar-nos a dar mais atenção a modos distintivamente locais (frequentemente orais) de re-presentar o passado. A hesitação é digna, e a advertência útil, não obstante o fato de não ser necessariamente ocidental a ideia de que a versão autorizada do passado é a escrita (ver, por exemplo, a concepção que tem os cingaleses de sua Grande Crônica, o Mahavansha).

19 Note as epígrafes tiradas de Robert H. Lowie e A. R. Radcliffe-Brown, que abrem o segundo capítulo, intitulado "Sobre os falantes / Para os leitores" ("Of speakers/ To readers" ${ }^{\prime \prime}$.

20 Parte do problema do argumento de Price é a confluência entre esses dois registros relacionados mas distinguíveis, a "atemporalidade" ("timelessness") e a "falta de passado" ("pastlessness" ). A "atemporalidade" é relacionada à suposta falta de profundidade histórica dos primitivos; a "falta de passado", à suposta falta, entre os negros, de um passado significativo. 
${ }^{21}$ O ensaio é intitulado "An Absence of Ruins?" ("Uma Ausência de Ruínas?"), uma alusão e crítica ao romance de 1967, An Absence of Ruins (Uma Ausência de Ruínas), de Orlando Patterson.

22 Para algumas considerações a respeito da relação entre o escritor das Índias Ocidentais e a história, ver Baugh (2012; 1978), Walcott (1974), Braithwaite (1974), McWatt (1982).

${ }^{23}$ Na verdade, Herskovits foi precedido por Morton C. Kahn, um pesquisador de "medidas públicas aplicadas a doenças tropicais" (Kahn, 1931, p. xvii). Kahn visitou os trópicos sul-americanos em 1922, 1923 e 1925, chegando "à fronteira dos territórios dos negros do mato", mas sua primeira visita aos "Djuka" foi empreendida em 1927 "sob os auspícios do Dr. Clark Wissler do Museu de História Natural, [e] com a assistência financeira do Dr. Myron I. Granger" (1931, p. xviii). Em sua segunda "expedição", em 1928, Kahn foi acompanhado por Herskovits.

24 Ver o ensaio engenhoso de Jackson (1986), ao qual devo muito. Para uma reflexão recente e generosa acerca de Herskovits, ver Fernandez (1990).

${ }^{25}$ Esta era a questão central desde o fim da Guerra Civil. Para uma discussão acerca dos debates sobre o status dos afro-americanos no período pós-reconstrução, ver Meier (1963).

${ }^{26}$ Relativo ao sociólogo britânico novecentista Matthew Arnold, em cuja obra "cultura" opera como um marcador de distinção com relação ao "filistinismo" e à "anarquia" [N. dos T.].

${ }^{27}$ A antologia de Locke jamais foi traduzida para o português, porém, a introdução do volume recebeu recentemente uma versão lusófona (Locke, 2011) [N. os T.].

${ }^{28}$ A ideia de "décimo talentoso" ("talented tenth") aponta para a proposta de criação de uma elite negra educada à moda clássica, visando o surgimento de líderes afro-americanos exemplares, engajados em mudanças sociais e "elevação racial". O termo, corrente na virada do século XIX, entra para o cânone da discussão acerca do negro norte-americano a partir de um ensaio de Du Bois (Du Bois, 1903) [N. dos T.].

${ }^{29}$ Na verdade, uma consciência afro-americana acerca da África já havia sido desenvolvida anteriormente. Ver, por exemplo, o estudo de Edwin Redkey acerca dos movimentos de retorno à África no século XIX (Redkey, 1969).

${ }^{30}$ Referente ao ensaísta branco Waldo Emerson, considerado no século XIX um dos fundadores de uma filosofia propriamente estadunidense. Foi mentor, por exemplo, de H. D. Thoreau [N. dos T.].

${ }^{31}$ Entre estes amigos estavam W. E. B. Du Bois, Alain Locke, James Weldon Johnson e Zora Neale Hurston. Um comentador recentemente chamou-o de um "Novo Negro honorário", e ele foi um dos únicos três brancos que contribuíram para The New Negro de Alain Locke (ver Lewis, 1979).

32 Tomei a expressão emprestada de George Stocking (1989, p. 209); mas ver também os usos que Herskovits faz dela (Herskovits, 1927, p. 217; 1930, p. 147).

33 Como enfatiza Herskovits, o termo "peculiarmente americano" de "aculturação" não é "de elaboração recente", tendo sido usado por etnólogos prominentes como W. J. Powell na segunda metade do século XIX (Herskovits, 1938, p. 1-2). Ver o argumento de Stocking (1968, p. 212) acerca das grandes diferenças entre o uso da expressão pelos evolucionistas e por Boas.

34 O próprio Herskovits sugeriu uma ligação direta entre suas novas ideias e a emergência do "Novo Negro" (1930, p. 151). 
${ }^{35}$ O texto original não marca o fato de que o estudo de Frances e Melville Herskovits na cidade focou exclusivamente nos surinameses de ascendência africana - a população urbana do país na década de 1920 era composta (como ainda é) também de uma quantidade expressiva de descendentes de indianos, javaneses e chineses, boa parte de chegada então recente. Para corrigir o compreensível erro (posto que Herskovits e Herskovits dão pouca atenção a este fato em seus escritos), o sufixo "afro-" foi acrescido ao substantivo "surinameses" [N. dos T.].

36 De fato, ele é bastante crítico dessa ideia herskovitsiana (Mintz; Price, 1976; Price, 1970).

37 Mais precisamente, o outro lado da concepção boasiana de cultura, que salientava "padrão", "estilo" e "ethos" de certa forma tomou o lugar dos "traços". Como expressa Stocking (1968, p. 214): "[...] por um lado, a cultura era simplesmente uma acumulação acidental de elementos individuais. Por outro, e ao mesmo tempo, apesar da renúncia de Boas ao crescimento orgânico, a cultura era uma totalidade espiritual integrada que de algum modo condicionava a forma de seus elementos".

38 Ver Asad ( 1986) para um didático debate acerca do conceito de "tradiçãa" no tocante ao islã.

39 Michael Manley foi Primeiro Ministro da Jamaica eleito duas vezes (1972-1980 e 1989-1992) pelo People's National Party - partido de orientação social-democrata, modernista, nacionalista e de classe média, fundado por seu pai, N. W. Manley. Seu legado é discutido por Scott (1999: 190-220) [N. dos T.].

${ }^{40}$ No caso das referências para as quais há traduções em português disponíveis, as listamos imediatamente depois das utilizadas pelo autor em seu texto original [N. dos T.].

\section{Referências}

APPADURAI, Arjun. Theory in Anthropology: Center and Periphery. Comparative Studies in Society and History, Ann Arbor, v. 26, n. 2, p. 356-361, 1986.

ASAD, Talal. The Idea of an Anthropology of Islam. Occasional Papers Series, Washington D.C.: Center for Contemporary Arab Studies, 1986.

BAUGH, Edward. The West Indian Writer and his Quarrel with History. Small Axe, New York, n. 38, p. 61-74, [1977] 2012.

BAUGH, Edward. Derek Walcott - Memory as Vision: Another Life. London: Longman, 1978.

BOAS, Franz. The Outlook for the American Negro. In: STOCKING Jr., George W. (Ed.). The Shaping of American Anthropology 1883-1911: A Franz Boas Reader. New York: Basic Books, [1906] 1974a. p. 310-315.

BOAS, Franz. A Perspectiva para o Negro Americano. In: STOCKING Jr., George W. (Ed.). A Formação da Antropologia Americana, 18831911. Tradução Rosaura Marina Cirne Lima Eichenberg. Rio de Janeiro: Contraponto; Editora UFRJ, [1906] 1999. p. 370-377. 
BOAS, Franz. Anthropology. In: STOCKING Jr., George W. (Ed.). The Shaping of American Anthropology 1883-1911: A Franz Boas Reader. New York: Basic Books, [1908] 1974b. p. 267-281.

BOAS, Franz. Antropologia. In: STOCKING Jr., George W. (Ed.). A

Formação da Antropologia Americana, 1883-1911. tradução Rosaura Marina Cirne Lima Eichenberg. Rio de Janeiro: Contraponto; Editora UFRJ, [1908] 1999, p. 323-340.

BOAS, Franz. Changes in Immigrant Body Form. In: STOCKING Jr., George W. (Ed.). The Shaping of American Anthropology 1883-1911: A Franz Boas Reader. New York: Basic Books, [1908] 1974c. p. 202-213.

BOAS, Franz. Mudanças na Forma Corporal dos Imigrantes. In: STOCKING Jr., George W. (Ed.). A Formação da Antropologia Americana, 18831911. Tradução Rosaura Marina Cirne Lima Eichenberg. Rio de Janeiro: Contraponto; Editora UFRJ, [1908] 1999. p. 244-258.

BORGES, Jorge Luis. Twenty Four Conversations with Borges. Tradução Nicomedes Suarez Arauz, Willis Barnstone e Noemi Escandell. New York: Grove, [1960] 1984.

BORGES, Jorge Luis. O Fazedor. Tradução Josely Vianna Baptista. São Paulo: Companhia das Letras, [1960] 2008.

BRATHWAITE, Edward. Timehri. In: COOMBS, Orde (Ed.). Is Massa Day Dead? Black Moods in the Caribbean. New York: Anchor, 1974. p. 2844.

CLIFFORD, James. Introduction: Partial Truths. In: CLIFFORD, James; MARCUS, George. (Ed.). Writing Culture: The Poetics and Politics of Ethnography. Berkeley: University of California Press, 1986. p. 1-26.

CLIFFORD, James. Introdução: Verdades Parciais. In: CLIFFORD, James; MARCUS, George (Ed.). A Escrita da Cultura: Poética e Política da Etnografia. Tradução de Maria Claudia Coelho. Rio de Janeiro: Papéis Selvagens; UERJ, [1986] 2016. p. 31-61.

DUBOIS, William Edward Burghardt. The Talented Tenth. In:

WASHINGTON, Booker T. et al. The Negro Problem: a Series of Articles by Representative American Negroes of Today. New York: James Pott and Company, 1903. p. 31-76.

DUBOIS, William Edward Burghardt. Black Folk, Then and Now: An Essay in the History and Sociology of the Negro Race. New York: Henry Holt, 1939.

DUBOIS, William Edward Burghardt. The Souls of Black Folk. New York: Bantam Books, [1903] 1989. 
DUBOIS, William Edward Burghardt. As Almas da Gente Negra. Rio de Janeiro: Lacerda, [1903] 1999, tradução Heloisa Toller Gomes.

FERNANDEZ, James W. Tolerance in a Repugnant World and Other Dilemmas in the Cultural Relativism of Melville J. Herskovits. In: FISKE, Alan Page (Ed.). Moral Relativism, Edição especial de Ethos, Chapel Hill, v. 18, n. 2, p. 140-164, 1990.

FREDRICKSON, George M. The Black Image in the White Mind: The Debate of Afro-American Character and Destiny, 1817-1914. New York: Harper, 1971.

HERSKOVITS, Melville J. The Negro's Americanism. In: LOCKE, Alain (Ed.). The New Negro. New York: Atheneum, 1925. p. 353-360.

HERSKOVITS, Melville J. Acculturation and the American Negro. The Southwestern Political and Social Science Quarterly, Austin, v. 8, n. 3, p. 211-224, 1927.

HERSKOVITS, Melville J. The Negro in the New World: The Statement of a Problem. American Anthropologist, new series, New Jersey, n. 32, p. 145-155, 1930.

HERSKOVITS, Melville J. The Myth of the Negro Past. New York: Beacon, 1941.

HERSKOVITS, Melville J. Acculturation: The Study of Culture Contact. New York: J. J. Augustin, 1938.

HERSKOVITS, Melville J.; HERSKOVITS, Frances. Rebel Destiny: Among the Bush Negroes of Dutch Guiana. New York: Books for Libraries Press, [1934] 1971a.

HERSKOVITS, Melville J. Life in a Haitian Valley. New York: Anchor, [1937] 1971b.

HUGGINS, Nathan (Ed.). Voices from the Harlem Renaissance. New York: Oxford University Press, 1976.

HUGGINS, Nathan. Harlem Renaissance. New York: Oxford University Press, 1979.

HYATT, Marshall. Franz Boas and the Struggle for Black Equality: The Dynamics of Ethnicity. Perspectives in American History, new series, Cambridge, n. 2, p. 269-95, 1985.

JACKSON, Walter. Melville Herskovits and the Search for Afro-American Culture. In: STOCKING Jr., George W. (Ed.). History of Anthropology, Malinowski, Rivers, Benedict and Others. Madison: University of Wisconsin Press, 1986. v. 4. p. 95-126. 
KAHN, Morton C. Djuka: The Bush Negroes of Dutch Guiana. New York: Viking, 1931.

KRUPAT, Arnold. Anthropology in the Ironic Mode: The Work of Franz Boas. Social Text, Durham, n. 19-20, p. 105-18, 1988.

LEWIS, David Levering. When Harlem was in Vogue. New York: Oxford University Press, 1979.

LOCKE, Alain (Ed.). The New Negro. New York: Atheneum, 1925.

LOCKE, Alain. O Novo Negro. In: SANCHES, Manuela Ribeiro (Org.).

Malhas que os Impérios Tecem: Textos Anticoloniais, Contextos Póscoloniais. Tradução Manuela Ribeiro Sanches. Lisboa: Edições 70, [1925] 2011, p. 59-72.

MARCUS, George E.; FISCHER, Michael M. J. Anthropology as Cultural Critique: An Experimental Moment in the Human Sciences. Chicago: University of Chicago Press, 1986.

McGRANE, Bernard. Beyond Anthropology: Society and the Other. New York: Columbia University Press, 1989.

McWATT, Mark. The Preoccupation with the Past in West Indian Literature. Caribbean Quarterly, Kingston, v. 28, n. 1-2, p. 12-19, 1982.

MINTZ, Sidney W.; PRICE, Richard. An Anthropological Approach to the Afro-American Past: A Caribbean Perspective. Philadelphia: Institute for the Study of Human Issues, 1976.

MINTZ, Sidney W.; PRICE, Richard. O Nascimento da Cultura AfroAmericana: uma perspectiva antropológica. Tradução de Vera Ribeiro. Rio de Janeiro: Pallas, [1976/1992] 2003.

MEIER, August. Negro Thought in America, 1880-1915. Ann Arbor: University of Michigan Press, 1963.

PATTERSON, Orlando. An Absence of Ruins. London: Hurchinson, 1967.

PRICE, Richard. Saramaka Woodcarving: The Development of an Afroamerican Art. Man, new series, London, v. 5, n. 3, p. 363-78, 1970.

PRICE, Richard. The Guiana Maroons: a Historical and Bibliographical Introduction, Baltimore: Johns Hopkins University Press, 1976.

PRICE, Richard. First-Time: The Historical Vision of an Afro-American People. Baltimore: Johns Hopkins University Press, 1983a.

PRICE, Richard. To Slay the Hydra: Dutch Colonial Perspectives on the Saramaka Wars. Ann Arbor: Karoma Publishers, 1983b.

PRICE, Richard. An Absence of Ruins?: Seeking Caribbean Historical Consciousness. Caribbean Review, Miami, v. 14, n. 3, p. 24-29; 45, 1985. 
PRICE, Richard. The Maroon Population Explosion: Suriname and Guyane. New West Indian Guide, Leiden, v. 87, n. 3-4, p. 323-327, 2013.

REDFIELD, Robert; LINTON, Ralph; HERSKOVITS, Melville J. Memorandum for the Study of Acculturation. American Anthropologist, new series, New Jersey, n. 38, p. 149-52, 1936.

REDKEY, Edwin S. Black Exodus: Black Nationalist and Back-to-Africa Movements, 1890-1910. New Haven: Yale University Press, 1969.

ROSALDO, Renato. Doing Oral History. Social Analysis, New York, n.4, p. 89-99, 1980a.

ROSALDO, Renato. Ilongot Headhunting, 1883-1974. Stanford: Stanford University Press, 1980b.

SCHOMBURG, Arthur. The Negro Digs Up His Past. In: LOCKE, Alain (Ed.). The New Negro. New York: Atheneum, 1925. p. 231-244.

SCOTT, David. Refashioning Futures: Criticism after Postcoloniality. Princeton: Princeton University Press, 1999.

STOCKING Jr., George W. Franz Boas and the Culture Concept in Historical Perspective. In: STOCKING Jr., George W. Race, Culture, and Evolution: Essays in the History of Anthropology. Chicago: University of Chicago Press, 1968, p. 195-233.

STOCKING Jr., George W. Anthropology as Kulturkampf: Science and Politics in the Career of Franz Boas. In: GOLDSCHMIDT, Walter (Ed.). The Uses of Anthropology. Washington: American Anthropological Association, 1979. p. 33-55.

STOCKING Jr., George W. The Ethnographic Sensibility of the 1920s and the Dualism of the Anthropological Tradition. In: STOCKING Jr., George W. (Ed.). History of Anthropology, vol. 6. Romantic Motives: Essays on Anthropological Sensibility. Madison: University of Wisconsin Press, 1989. p. 208-277.

SZWED, John F. An American Anthropological Dilemma: The Politics of Afro-American Culture. In: HYMES, Dell (Ed.). Reinventing Anthropology. New York: Vintage, 1974, p. 153-181.

WALCOTT, Derek. The Muse of History: An Essay. In: COOMBS, Orde (Ed.). Is Massa Day Dead? Black Moods in the Caribbean. New York: Anchor, 1974, p. 1-27.

WHITE, Hayden. Interpretation in History. In: WHITE, Hayden. Tropics of Discourse: Essays in Cultural Criticism. Baltimore: Johns Hopkins University Press, 1978. p. 51-80. 
WHITE, Hayden. A Interpretação na História. In: WHITE, Hayden. Trópicos do Discurso: Ensaios sobre a Crítica da Cultura. Tradução Alípio Correia de Franca Neto. São Paulo: EdUSP, [1978] 1994. p. 65-96. WILLIS, William. Anthropology and Negroes on the Southern Colonial Frontier. In: CURTIS, James C.; GOULD, Lewis L. (Ed.). The Black Experience in America: Selected Essays. Austin: University of Texas University Press, 1970, p. 33-50.

Recebido em 03/08/2017

Aceito em 04/10/2017 